Journal of Biodiversity and Environmental Sciences (JBES)

ISSN: 2220-6663 (Print) 2222-3045 (Online)

Vol. 12, No. 1, p. 1-4, 2018

http://www.innspub.net

INNSPUB

\title{
In vitro antimalarial activity of essential oils of Deverra scoparia Coss. \& Dur
}

\author{
Roukia Hammoudi* ${ }^{*}$, Soulaymene Sanon ${ }^{2}$, Mahfoud Hadj Mahammed ${ }^{3}$ \\ ${ }^{\prime}$ Department of Biological Sciences, Biogeochemistry Laboratory in Desert Environments, \\ University of Ouargla, Ouargla, Algeria \\ ${ }^{2}$ National Centre for Research and Training on Malaria, Ouagadougou, Burkina Faso \\ ${ }^{s}$ Department of Chemistry, Biogeochemistry Laboratory in Desert Environments, \\ University of Ouargla, Ouargla, Algeria
}

Article published on January 20, 2018

Key words: Antimalarial, Activity, Essential oil, Deverra scoparia, Apiaceae.

\begin{abstract}
The essential oils of the plant Deverra scoparia Coss. \& Dur. (Apiaceae) used in traditional medicine in Algeria were subjected to testing the antimalarial activity. Their potential ability to inhibit the in vitro proliferation was evaluated in two strains of Plasmodium falciparum; chloroquine-resistant (K1), and chloroquine-sensitive (3d7) strains. The essential oils displayed good antimalarial activity with $\mathrm{IC}_{50}$ values $1.51 \pm 0.71 \mu \mathrm{g} / \mathrm{mL}$ and $0.93 \pm 0.89$ $\mu \mathrm{g} / \mathrm{mL}$ against the $3 \mathrm{~d} 7$ chloroquine-sensitive and the K1 chloroquine-resistantstrains respectively. So, Deverra scoparia presented a potential source of antimalarial molecules.
\end{abstract}

*Corresponding Author: Roukia Hammoudi $\bowtie$ rokia1811@yahoo.com 


\section{Introduction}

The genus Deverra or Pituranthos (Apiaceae) is a perennial plant (Ozenda, 1983), possesses more than twenty species, some of which are specific to northern Africa and are often found in arid or desert regions (Quezel and Santa, 1963). In Algeria, this genus has (o3) three endemic species: Deverra scoparia Coss. \& Dur. or Pituranthos scoparius Benth. \& Hook; Pituranthos chloranthus Benth. \& Hook; Pituranthos battandrieri (Ozenda, 1983). The genus Deverra is widely used in traditional pharmacopoeia in many areas and the pharmacological properties of some species have been validated by appropriate tests (Abdelwahed et al., 2006; Djeridane et al., 2008). Some species are used against diabetes, fever, urinary tract infections, stomach pain, intestinal parasites, asthma, hepatitis and to relieve the pain associated with rheumatism (Bellakhdar, 1997; Hammiche et al., 2006).

Malaria is a potentially fatal parasitic disease caused by protozoa of the genus Plasmodium. P. falciparum, the specie responsible for the vast majority of infections (Kamatou et al., 2008). The disease remains a global problem with consequences for both the health and economic potential of the world's poorest endemoepidemic communities. There were an estimated 247 million malaria cases among3.3 billion people at risk in 2006, causing nearly a million deaths, mostly of children under 5 years. 109 countries were endemic for malaria in 2008, 45 within the WHO African region. In 2007, according to the WHO report, about $40 \%$ of the world's population, mostly in the poorest countries of the world, is exposed to malaria. Every year, more than 500 million people are seriously affected (WHO, 2008).In Algeria, however, malaria cases has occurred regularly since the 1980 s introduced by infected patients using the newtrans-Sahara route. In 2002,for example, 300 malaria cases were recorded in Algeria, 255 of them were imported (Hammadi et al., 2009).Drug resistance of malaria parasites has become an issue of utmost concern and complicates treatment, but an antimalarial vaccine that could be protective against this disease is not yet available.
It is also necessary to find new effective and affordable therapies. Medicinal plants could be a potential source of antimalarial agents (Sanon et al., 2013). A view of literature has not revealed any previous researches on the antimalarial activity of Deverra scoparia Coss. \& Dur. essential oils.

\section{Materials and methods}

Plant material

The aerial parts of D. scoparia Coss. \& Dur. were collected during January 2013 from Tamanrasset $\left(23^{\circ}\right.$ $81^{\prime} 756^{\prime \prime} \mathrm{N}, 5^{\circ}$ 93' 888" E), south of Algeria. The identification was performed according to botanists of the National Forest Research Institute in Tamanrasset. The voucher specimens (PM/O2) were available at the Herbarium of the Laboratory of Biogeochemistry of Desert Environments, University of Ouargla, Algeria.

\section{Essential oil extraction}

The essential oils from dried plant were extracted by hydrodistillation using a Clevenger-type apparatus for $4 \mathrm{~h}$. The oils were stored in sealed glass vials at $4^{\circ} \mathrm{C}$ prior to analysis.

\section{Antimalarial activity}

The essential oils of $D$. scoparia were tested in vitro against two reference clones of Plasmodium falciparum: the chloroquine-resistant (K1) and the chloroquine-sensitive ( $3 \mathrm{~d} 7)$ strains. The malaria strains were maintained in continuous culture in $\mathrm{O}^{+}$ human erythrocytes using RPMI 1640 (Mega Cell, Sigma Aldrich, USA) medium supplemented with 2hydroxyethlpiperazine- N-2ethanesulfonic acid (HEPES acid) (25mM; Gibco-BRL, Paisley, Scotland), $\mathrm{NaHCO}_{3}(25 \mathrm{mM}), \quad 1 \%$ Albumax and washed erythrocytes to yield a final haematocrit of $4 \%$. The culture flasks were incubated at $37^{\circ} \mathrm{C}$ in a $\mathrm{CO}_{2}$ incubator (Hera Cell 150, Forma Scientific), with 2\% $\mathrm{O}_{2}, 5 \% \mathrm{CO}_{2}, 93 \% \mathrm{~N}_{2}$ and $90 \%$ humidity.

The essential oils or reference control (chloroquine diphosphate salt (CQ) (Sigma Aldrich) was applied in a series of seven duplicate dilutions and dissolved in DMSO. 
Infected and non-infected erythrocytes $\mathrm{O}^{+}$were used as positive and negative controls, respectively. Parasite growth was determined by measuring the content of Plasmodium lactate dehydrogenase (pLDH) using Malstat, NTB/PES reagents. The 96well microplates were read using a spectrophotometer (Biotek EL x 808) at a wavelength of $650 \mathrm{~nm}$ (Sanon et al., 2013). MatLab version 2016 was used to plot inhibition curves and calculate the inhibition concentrations of drugs that reduced the level of parasitaemia to $50 \%\left(\mathrm{IC}_{50}\right)$.

\section{Results and discussion}

The result of the in vitro antimalarial activity of Deverra essential oils against the chIoroquineresistant and the chloroquine-sensitive $P$. falciparum was shown in Table 1.

Table 1. $\mathrm{IC}_{50}$ values of the antimalarial activity of the essential oils against $P$. falciparum.

\begin{tabular}{lcc}
\hline Antimalarial activity & $\mathrm{IC}_{50}(3 \mathrm{~d} 7)(\mu \mathrm{g} / \mathrm{mL})$ & $\mathrm{IC}_{50}(\mathrm{k} 1)(\mu \mathrm{g} / \mathrm{mL})$ \\
\hline Essential oils & $1.51 \pm 0.71$ & $0.93 \pm 0.89$ \\
Reference control (CQ) & $4.81 \pm 1.17$ & $23.36 \pm 1.17$
\end{tabular}

$\overline{\mathrm{CQ}}$, chloroquine diphosphate salt; K1, chIoroquine-resistant $P$. falciparum; $3 \mathrm{~d} 7$, chloroquine-sensitive $P$. falciparum.

The essential oils have a good antimalarial activity with $\mathrm{IC}_{50}$ value: $1.51 \pm 0.71 \mu \mathrm{g} / \mathrm{mL}$ against the $3 \mathrm{~d} 7$ strain and $0.93 \pm 0.89 \mu \mathrm{g} / \mathrm{mL}$ against $\mathrm{K} 1$. The essential oils were more potent against the parasites than the antimalarial reference (CQ) (IC50 values: $4.81 \pm 1.17$ and $23.36 \pm 1.17 \mu \mathrm{g} / \mathrm{mL}$ against $3 \mathrm{~d} 7$ and $\mathrm{K} 1$ respectively.

Less of in vitro studies demonstrated that Deverra species displayed antiplasmodial activity. $\alpha$-Bornyl acetate (31.99\%) and $\alpha$-Pinene (12.05\%) were the major compounds detected in the essential oils of D.scoparia from south Algeria (Hammoudi et al., 2015). These compounds may therefore be responsible for the antimalarial activity of the oils.

Kamatou et al. (2008) confirmed that the antimalarial activity of essential oils may be attributed to their high sesquiterpene content.

In theory, fractionation leading to the isolation of individual compounds should result in aliquots having higher activity than the original extract. The activity may also be due to the fact that synergy or antagonist might account for the better activity of mixture than isolated compounds or inverse (Kamatou et al., 2008).
In this study, The essential oils of Deverra scoparia showed good antimalarial activity with $\mathrm{IC}_{50}<$ $5 \mu \mathrm{g} / \mathrm{mL}$. So, it is suggested that future studies should consider this plant as a potential source of antiplasmodial molecules.

A further study is also necessary to determine the toxicity of the essential oils and their components.

\section{Acknowledgement}

The authors wish to thank the National Centre for Research and Training on Malaria, Burkina Faso for all the chemicals, instruments, and apparatus supplied for this study.

\section{References}

Abdelwahed A, Hayder N, Kilani S, Mahmoud A, Chibani J, Hammami M, Chekir-Ghedira L, Ghedira K. 2006. Chemical composition and antimicrobial activity of essential oils from Tunisian Pituranthos tortuosus (Coss.) Maire. Flavour And Fragrance Journal 21(o1), 129-133.

Bellakhdar J. 1997. Médecine Arabe Ancienne et Savoirs Populaires, La pharmacopée marocaine traditionnelle. Ibis Press. 
Djeridane A, Brunel JM, Vidal N, Yousfi M, Ajandouz EH, Stocker P. 2008. Inhibition of porcine liver carboxylesterase by a new flavones glucoside isolated from Deverra scoparia. ChemicoBiological Interactions 172, 22-26.

Hammadi D, Boubidi SC, Chaib SE, Saber A, Khechache Y, Gasmi M, Harrat Z. 2009. Le paludisme au Sahara algérien. Bulletin de la Société de Pathologie Exotique 102 (3), 185-192.

Hammiche V,Maiza K. 2006. Traditional medicine in Central Sahara: Pharmacopoeia of Tassili N'ajjer. Journal of Ethnopharmacology 105, 358-367.

Hammoudi R, Dehak K, Hadj Mahammed M, Ouldelhadj MD. 2015. Composition chimique et activité antioxydante des huiles essentielles de Deverra scoparia Coss. \& Dur. (Apiaceae). Lebanese Science Journal 16(2), 27-36.
Kamatou PP, Van Zyl RL, Davids H, Van Heerden FR, Lourens ACU, Viljoen AM. 2008. Antimalarial and anticancer activities of selected South African Salvia species and isolated compound from S. radula. South African Journal of Botany 74, 238-243.

Ozenda P. 1983. Flore du Sahara. Éd. 2, Centre National de la Recherche Scientifique CNRS, Paris.

Quezel P, Santa, S. 1963. Nouvelle Flore d'Algérie et des régions Désertiques Méridionales. Tome I et II. CNRS.

Sanon S, Gansana A, Ouattara LP, Traore A, Ouedraogo IN, Tiono A, Taramelli D, Basilico N, Sirima SB. 2013. In vitro antiplasmodial and cytotoxic properties of some medicinal plants from western Burkina Faso. African Journal of Laboratory Medicine 2(1): 7pages.

http://dx.doi.org/10.4102/ajlm.v2i1.81

WHO. 2008. World Malaria Report, Geneva 